\title{
The Impact of Funding Sources on Corporate Liquidity in Energy Sector in the Czech Republic
}

\author{
Markéta Šeligová \\ Department of Finance and Accounting, Faculty of Business Administration in Karviná, \\ Silesian University in Opava, Univerzitní nám. 1934/3, 73340 Karviná, Czech Republic \\ E-mail: seligova@opf.slu.cz
}

Received 15 March 2017; accepted 05 April 2017

\begin{abstract}
The aim of this paper is to determine the impact of funding sources on liquidity of companies in energy sector in the Czech Republic. With the purpose to fulfill the aim, we examine existence and character of relationship between selected financial factors (debt equity ratio, share of capital for consideration to total assets, return on equity, share of fixed assets to total assets, share of earnings before interest and taxes to total assets, equity ratio) and liquidity of the companies in energy sector in the Czech Republic. The existence of relationship between financial factors and liquidity of companies is tested by correlation analysis and generalized method of moments called GMM method. It is expected a positive relationship between liquidity and funding sources in energy sectors in the Czech Republic. Companies with high liquidity are more credible and less risky clients for creditors and can obtain the necessary financial support under more favorable and cheaper terms.
\end{abstract}

Keywords: correlation, debt equity ratio, fixed assets, generalized method of moments, leverage ratio, liquidity, return on equity.

JEL Classification: G32, G34, G39.

Conference topic: Modern Business Management Problems and Perspectives.

\section{Introduction}

Myers (2001) argues that agency effects of various kinds may create important reasons for holding liquid assets with the further implications of different patterns of corporate liquidity depending on capital structure or other firm characteristics. He believed that holding liquid assets will be important for companies facing growth opportunities and the expected return fluctuates over time. Given that the decision on liquidity associated with the debt structure of companies, each of them needs to monitor its liquidity relations following the decision of debt. Liquidity is a key financial indicator to measure whether the company is able to meet its debt obligations based on short-term debt ratio, long-term debt ratio and total debt ratio without causing undesirable losses. Stulz (1990) argues that firms with high leverage and losing their financial flexibility, may have difficulty in finding new funds to finance their projects. Sarlija and Harc (2012) suggest that liquidity is a characteristic of the company's assets that can be quickly converted to cash. Firms hold a certain amount of liquidity in during their activities to be able to meets its obligations on time. For this reason, Saleem and Rehman (2011) argues that liquidity management is very important for each company in order to maintain the ability to pay its obligations properly and on time.

The aim of this paper is to determine the impact of funding sources on liquidity of companies in energy sector in the Czech Republic from 2007 to 2015. With the purpose to fulfill the aim, we examine existence and character of relationship between selected financial factors (debt equity ratio, share of capital for consideration to total assets, return on equity, share of fixed assets to total assets, share of earnings before interest and taxes to total assets, equity ratio) and liquidity of the companies in energy sector in the Czech Republic.

The first part of this article will include a literature review. The second part of this article will focused on methodology and data. The third part of this article will contain results and discussion. Last part of this article will conclude results.

(C) 2017 M. Šeligová. Published by VGTU Press. This is an open-access article distributed under the terms of the Creative Commons Attribution (CC BY 4.0) License, which permits unrestricted use, distribution, and reproduction in any medium, provided the original author and source are credited. 


\section{Literature Review}

Williamson (1988), Shleifer and Vishny (2003), Anderson (2002) believe that more liquid companies are less costly to monitor and liquidate therefore higher liquidity growth leverage. On the contrary, De Jong et al. (2008), Lispon and Mortal (2009), Šarlija and Harc (2012) argue that more liquid companies are less indebted, because they could use the additional liquidity to internally finance their activities.

The aim of this paper is to determine the impact of funding sources on liquidity of companies in energy sector in the Czech Republic. For this reason, it would be appropriate to mention a study focusing on the liquidity of companies in the Czech Republic. Unfortunately, there are few studies focusing on the liquidity of companies in the Czech Republic. For this reason, the literature review will be supplemented with additional relevant studies focusing on the liquidity of companies in other countries.

Anderson (2002) examined the relationships among the firm's financial structure, its choice of liquid asset holdings and growth on UK and Belgian companies. Using regression analysis he examined the factors determining liquid asset holdings and the link between firm liquidity and capital structure using the following variables: liquidity (dependent variable, sum of cash, bank balances, and investments in current assets divided by total assets) and independent variables such as cash flow (earnings before taxes and interest divided by total assets), long term debt, medium term debt, short term debt, R\&D expenditures and market value to book value. The results revealed positive associations between leverage and liquid asset holding.

One of funding sources are depreciation that are related with fixed assets. For this reason, it is appropriate to examine the relationship between liquidity of companies and depreciation through fixed assets. Unfortunately, there is only minimum specific studies that focus on this relationship. For this reason, study of Mehar (2005) was selected to the literature review. He examined whether equity financing plays a central role in determination of the liquidity position of a companies in Pakistan. The relation between the equities and working capital has been observed. He analyzed relation between liquid assets (dependent variable) and independent variables such as fixed assets at historical cost, net profit after tax and retained earnings. There was found that liquidity is positively correlated with fixed assets. An increase in the fixed assets will lead to the increase in depreciation expenditure, so, availability of the funds will be increased without a decline in the cash balance. He found that depreciation fund has been classified as a source of liquidity. The long-term debt may deteriorate the liquidity position of a firm. The results shows that profit and liquidity have significant positive relation where relation between liquidity and retained earnings was found as negative.

Shah (2012) examined relationship between profitability and liquidity trade off through the application of working capital analysis in India. This study undertakes the identification of the key variables that influence the working capital management and its impact on profitability and liquidity of pharmaceuticals manufacturers. He examined the relationship between liquidity (dependent variable, including current ratio) and independent variables (components of working capital) such as gross operating cycle period and quick ratio. It has been found that there is a positive relationship between liquidity and variables such as quick ratio and gross operating cycle period. He examined the relationship between liquidity (current ratio) and profitability (earnings before depreciation, interest, and tax as a percentage of assets). It has been found that there is a negative relationship between liquidity and profitability.

Šarlija and Harc (2012) investigated the impact of liquidity on the capital structure of Croatian firms. Pearson correlation coefficient was applied to the test on the relationship between liquidity ratios and debt ratios, the share of retained earnings to capital and liquidity ratios and the relationship between the structure of current assets and leverage. The results showed the existence of a statistically significant negative correlations between liquidity ratios and leverage ratios. The results showed that there are statistically significant correlations between leverage ratios and the structure of current assets. The relationship between liquidity ratios and the short-term leverage is stronger and negative than positive relationship between liquidity ratios and the long-term leverage. The more liquid assets firms have, the less they are leveraged. Long-term leveraged firms are more liquid. Increasing inventory levels leads to an increase in leverage. Furthermore, increasing the cash in current assets leads to a reduction in the short-term and the long-term leverage.

Trippner (2013) analyzed the relationship between liquidity (cash ratio, current ratio and quick ratio) and profitability (return on assets - ROA, return on equity - ROE) in the Polish company from 2002 to 2012. Using correlation analysis it has been found that there is a positive and negative relation between liquidity and ROA and ROE.

Milos (2015) analyzed the determinants of capital structure of the Romanian companies using panel data. He used variables including ratio between total debt and total liabilities, profitability (return on assets), liquidity (ratio between current assets and current liabilities), tangibility (ratio of tangible assets divided by the total assets) and size (natural logarithm of total sales). The results show that there is a negative connection between liquidity and leverage. The results suggest that less liquid companies obtain the necessary capital by borrowing. Companies often prefer and use a short-term loans when there is a lack of liquidity.

Růčková (2015) analyzed the impact of liquidity and profitability on use of deb finance sources of companies in manufacturing industry in V4 countries. She examined the relationship between using debt sources (debt/equity ratio) and liquidity. The study results showed a positive relationship between liquidity and using debt sources in the Czech Republic. It can be stated that the increasing liquidity of companies is also increasing the using debt sources. 
From a theoretical point of view, a very important indicator is the coverage ratio represented a share of capital for consideration to total assets. This indicator represents the state of the capitalization of the company. A value less than 1 represent to thin capitalization of company. That is inadequately equipped venture capital. A value greater than or equal to 1 represent a large capitalization company. This means that the company has a large enough volume of capital. The recommended value is $100 \%$ or more. Based on these facts, it is expected a positive relationship between share of capital for consideration to total assets and liquidity of companies. The greater the value of this indicator, the greater the amount of capital is available to the company, leading to the growth of liquidity of companies.

From a theoretical perspective too, a very imporatnat indicator is the equity ratio. The equity ratio is a financial ratio indicating the relative proportion of equity used to finance a company's assets. The equity ratio is a good indicator of the level of leverage used by a company. The equity ratio measures the proportion of the total assets that are financed by stockholders, as opposed to creditors. A low equity ratio will produce good results for stockholders as long as the company earns a rate of return on assets that is greater than the interest rate paid to creditors. It is expected a negative relationship between equity ratio and corporate liquidity. The more liquid assets firms have, the less they are leveraged. The advantage of a lower amount of equity is usually lower cost debt sources than the cost of equity, however, if the company is highly indebted and its financial stability impaired, creditors increase the cost of their resources and the positive effect of savings in financing of debt sources is gone.

\section{Methodology and Data}

Given that the article focuses on liquidity of companies in Czech Republic, it is appropriate to mention that various sectors of the economy are involved to varying degrees in the consumption and production of the national economy. The sectors such as mining and quarrying, manufacturing, construction, service sector and energy sector represent the largest proportion of the performance of Czech economy. For this reason, the article focuses on determine the relationship between the funding sources and liquidity of the companies in energy sector.

All financial date are taken from Amadeus database. This database includes data from the annual reports of individual companies in the Czech Republic. The dataset cover the period 2007-2015. All data and time series are on annual frequency. The data are the basis for the application of correlation analysis and panel regression analysis, specifically generalized mothod of moments (GMM).

The aim of this paper is to determine the impact of funding sources on liquidity of companies in energy sector in the Czech Republic from 2007 to 2015. With the purpose to fulfill the aim, we examine existence and character of relationship between selected financial factors (debt equity ratio, share of capital for consideration to total assets, return on equity, share of fixed assets to total assets, share of earnings before interest and taxes to total assets, equity ratio) and liquidity of the companies in energy sector in the Czech Republic.

We can define relationship between liquidity of companies and funding sources based on the above studies and formulated goals. This relationship will be identified for energy. We will examine how funding sources affect liquidity of companies.

Correlation analysis and generalized method of moments (GMM) is used to determine the relationship between liquidity of companies and funding sources. First, we can determine the relationship between liquidity of companies and funding sources using correlation analysis. The correlation can be expressed by the following Eq. (1):

$$
K_{X Y}=\frac{\operatorname{cov}(X, Y)}{\sigma_{X} \sigma_{Y}} .
$$

Where $X$ is the mean value matrix liquidity of companies and $Y$ is the mean value matrix of debt equity ratio, share of capital for consideration to total assets, return on equity, share of fixed assets to total assets, share of earnings before interest and taxes to total assets, equity ratio. This indicator should be in the interval from -1 to 1 . Values closer to the value of 1 would suggest that with increased liquidity of companies is growing debt equity ratio, share of capital for consideration to total assets, return on equity, share of fixed assets to total assets, share of earnings before interest and taxes to total assets, equity ratio. Values closer to the value of -1 would suggest that with decreased liquidity of companies is growing debt equity ratio, share of capital for consideration to total assets, return on equity, share of fixed assets to total assets, share of earnings before interest and taxes to total assets, equity ratio. Values which are zero signal independent of one another.

The generalized method of moments (GMM) is used in econometrics and statistics. The generalized method of moments (GMM) is a generic method for estimating parameters in statistical models. It is applied in the context of semiparametric models, where the parameter of interest is finite-dimensional, whereas the full shape of the distribution function of the data may not be known, and therefore maximum likelihood estimation is not applicable. The method requires that a certain number of moment conditions were specified for the model. These moment conditions are functions of the model parameters and the data, such that their expectation is zero at the true values of the parameters. The GMM method then minimizes a certain norm of the sample averages of the moment conditions. The GMM estimators are known to be consistent, asymptotically normal, and efficient in the class of all estimators that do not use any extra information aside from that contained in the moment conditions. (Hansen 1982). 
I will draw from the Haas aand Lelyveld (2010) to construct the model. The relationship between liquidity of companies and funding sources will be estimated using the following equations in general form (2):

$$
L_{i t}=\alpha_{1}+\beta_{1} * \Delta L_{i t-1}+\beta_{2} * X_{1 i t}+\beta_{3} * X_{2 i t}+\ldots \ldots . .+\beta_{n} * X_{n i t}+\varepsilon_{i t} .
$$

In consistent with studies Anderson (2002), Mehar (2005), Trippner (2013) and Růčková (2015), variables include debt equity ratio (DER), return on equity (ROE), share of fixed assets to total assets (FA/TA) and share of earnings before interest and taxes to total assets (EBIT), equity ratio (ER) and share of capital for consideration to total assets (DE/A).

The dependent variable $L_{t}$ is an indicator of current liquidity (L3) of companies in the Czech Republic at time $t$, $X_{n t}$ are other factors that represent funding sources and which may affect the liquidity of companies in the Czech Republic. These factors include debt equity ratio (DER), return on equity (ROE), share of fixed assets to total assets (FATTA), share of earnings before interest and taxes to total assets (EBIT), equity ratio (ER) and share of capital for consideration to total assets (DE/TA). $\beta_{0}$ and $\varepsilon_{t}$ is model constant and the residual component in the model.

Table 1. Description of used variables (Source: Authors' calculations)

\begin{tabular}{llc}
\hline \multicolumn{1}{c}{ Variables } & \multicolumn{1}{c}{ Calculation } & Expected relationship \\
\hline Liquidity (L3) & Current assets/ current liabilities & Dependent variable \\
Debt equity ratio (DER) & Debt/equity & - \\
Return on equity (ROE) & Net profit/ equity & + \\
Fixed assets (FA/TA) & Fixed assets/total assets & + \\
Earnings before interest and taxes (EBIT) & Earnings before interest and taxes/total assets & $+/-$ \\
Equity ratio & Equity / total assets & - \\
Share of capital for consideration to total & The sum of equity and debt sources / total assets & + \\
assets (DE/TA) & & \\
\hline
\end{tabular}

Table 1 represents description of used variables. The funding sources are represented through the variables (debt equity ratio, return on equity, share of fixed assets to total assets, share of earnings before interest and taxes to total assets, share of capital for consideration to total assets, equity ratio). The financial ratios (variables) are used to determine relationship between funding sources and liquidity of companies. The choice of variables is based on the above studies.

The liquidity ratio is very important indicator because liquid company only is able to pay its payables. If the company has a sufficient amount of funds for payment of its current liabilities, the company will be liquid. An excessively high value of liquidity is usually accompanied by lower values of equity (return on equity) that is associated with a conservative approach. On the other hand, companies that have too low levels of liquidity typically use debt sources for financing their activities.

Debt equity ratio (leverage) measures debt sources to equity. The higher value of the debt equity ratio, the higher ratio of debt sources to equity. This fact can indicate a higher risk for creditors. The value of debt equity ratio 1 indicates that equity and debt sources are involved in the financing of companies in the same amount. Higher debt represents a higher level of risk of companies. On the other hand, higher debt may mean a larger volume of funding sources because the costs of external funding tend to be cheaper than costs of equity. Companies that have too low levels of liquidity typically use debt sources for financing their activities. For this reason, we can expect a negative relationship between liquidity of companies and debt equity ratio. This fact is consistent with study Miloş (2015) who found negative relationship between liquidity and debt equity ratio.

The return on equity (ROE) is important especially for the owners of the company or competing companies. The return on equity shows how efficiently a company uses its own equity (funds of owners of company). Return on equity can also affect the costs of external funding (debt sources). Positive relationship between liquidity of companies and return on equity is expected based on the study Trippner (2013). More profitable companies are the ones that can use their retained earnings in order to finance their investment projects.

A higher value of fixed assets always requires a higher value of liquid assets. An increase in the fixed assets will lead to the increase in depreciation expenditure, so, availability of the funds will be increased without a decline in the cash balance. Fixed assets present a crucial role in ensuring the necessary collateral for bank borrowing and raising secured debt. A low level of fixed assets could decrease the volume of debt that the company may achieve. A high level of fixed assets may ensure cheaper debt resources and lowers the risk taken by the creditor. On the other hand, the companies rely more on short-term debt than on long-term debt in which case the collateral is not so important. The companies with high-valued fixed assets rather use their retained earnings or issue equity than finance their activity by increasing indebtedness. Another explanation could arise from the fact that usually, in emerging economies, companies rely more on short-term loans rather than long-term ones, consequently the importance of collateral is reduced. 
In consistent with this fact, there is expected a positive relationship between liquidity of companies and share of fixed assets to total assets.

Companies with higher earnings and less volatility in earnings are the ones that have greater indebtedness, due to the increased credibility in front of potential creditors. Moreover, they have more income to shield from taxes. On the other hand, more profitable companies are the ones that can use their retained earnings in order to finance their investment projects. An excessively high value of liquidity is usually accompanied by lower values of profitability that is associated with a conservative approach. On the other hand, Trippner (2013) found a positive and negative relation between liquidity of companies and share of earnings before interest and taxes to total assets. In consistent with these facts, it is not clear what relationship can be expected. Therefore, the resulting relationship will be determined using panel regression analysis, specifically generalized method of moments.

From a theoretical point of view, a very important indicator is the coverage ratio represented a share of capital for consideration to total assets. This indicator represents the state of the capitalization of the company. A value less than 1 represent to thin capitalization of company. That is inadequately equipped venture capital. A value greater than or equal to 1 represent a large capitalization company. This means that the company has a large enough volume of capital. The recommended value is $100 \%$ or more. Based on these facts, it is expected a positive relationship between share of capital for consideration to total assets and liquidity of companies. The greater the value of this indicator, the greater the amount of capital is available to the company, leading to the growth of liquidity of companies.

From a theoretical perspective too, a very imporatnat indicator is the equity ratio. The equity ratio is a financial ratio indicating the relative proportion of equity used to finance a company's assets. The equity ratio is a good indicator of the level of leverage used by a company. The equity ratio measures the proportion of the total assets that are financed by stockholders, as opposed to creditors. A low equity ratio will produce good results for stockholders as long as the company earns a rate of return on assets that is greater than the interest rate paid to creditors. It is expected a negative relationship between equity ratio and corporate liquidity. The more liquid assets firms have, the less they are leveraged. The advantage of a lower amount of equity is usually lower cost debt sources than the cost of equity, however, if the company is highly indebted and its financial stability impaired, creditors increase the cost of their resources and the positive effect of savings in financing of debt sources is gone.

\section{Results and Discussion}

This part focuses on the results of correlation analysis, generalized method of moments (GMM) and their comments. First, we can determine the relationship between liquidity of companies and funding sources using correlation analysis. The following Table 2 reflect the degree of interdependence of monitored parameters in energy sector in the Czech Republic.

Table 2. Correlation between liquidity of companies and funding sources in energy sector (Source: Authors' calculations)

\begin{tabular}{ccccccc}
\hline & DER & ROE & FA/TA & EBIT & ER & DE/TA \\
\hline Liquidity L3 & -0.007457 & 0.002802 & -0.042887 & 0.003357 & 0.316481 & -0.316726 \\
\hline
\end{tabular}

Table 2 presents correlative relationship between liquidity of companies (dependent variable) and independent variables such as debt equity ratio, return on equity, share of fixed assets to total assets, share of earnings before interest and taxes to total assets, share of capital for consideration to total assets, equity ratio in energy sector in the Czech Republic. From this Table 2 is evident that there is insignificant correlation between corporate liquidity and funging sources in energy sector in the Czech Republic. The relationship between corporate liquidity and funding sources appers as uncorrelated. The correlation is close to 0 . The highest correlation was observed for the variables such as equity ratio and share of capital for consideration to total assets. The positive correlation coefficient is 0,316481 for relationship between corporate liquidity and equity ratio. This means that there is a positive correlation between liquidity of companies and equity ratio (ER). The results suggest that with increase in equity ratio increases corporate liquidity in energy sector in the Czech Republic. On the other hand, there was found the negative relationship between corporate liquidity and share of capital for consideration to total assets (DE/TA).

The correlation coefficient is $-0,316726$. This means that with decrease in share of capital for consideration to total assets increases liquidity of companies in energy sector in the Czech Republic.

Using correlation analysis we found that there is positive, negative and no relationship between liquidity of companies in energy sector in the Czech Republic and independent variables (funding sources). The resulting correlation relationship appers as uncorrelated. Generalized method of moment (GMM) will be used to determine, how significant will be the relationship between liquidity of companies and funding sources. Debt equity ratio (leverage) measures debt sources to equity. The higher value of the debt equity ratio, the higher ratio of debt sources to equity. This fact can indicate a higher risk for creditors. On the other hand, share of capital for consideration to total assets measures the sum of equity and debt sources to total assets. For this reason, to determine the relationship between corporate 
liquidity and funding sources will be estimated two equations. One equation will include debt equity ratio as the independent variable. The second equation will include share of capital for consideration to total assets as the independent variable. This relationship is expressed by the following Eqs (3) and (4).

$$
\begin{gathered}
L_{i t}=\alpha_{1}+\beta_{1} * \Delta L_{i t-1}+\beta_{2} * D E R_{i t}+\beta_{3} * R O E_{i t}+\beta_{4} * F A / T A_{i t}+\beta_{5} * E B I T_{i t}+\beta_{6} * E R_{i t}+\varepsilon_{i t} \\
L_{i t}=\alpha_{1}+\beta_{1} * \Delta L_{i t-1}+\beta_{2} * D E / T A_{i t}+\beta_{3} * R O E_{i t}+\beta_{4} * F A / T A_{i t}+\beta_{5} * E B I T_{i t}+\beta_{6} * E R_{i t}+\varepsilon_{i t}
\end{gathered}
$$

Table 3 presents the resulting relationship between liquidity companies (dependent variables) and funding sources (independent variables) using indicator debt equity ratio (DER)

Table 3. Estimation results between liquidity of companies and funding sources in energy sector wit debt equity ratio (Source: Authors' calculations)

\begin{tabular}{ccccc}
\hline Variable & Coefficient & Std. Error & t-Statistic & Prob. \\
\hline ER & 7.178679 & 1.309279 & 5.482925 & 0.0000 \\
EBIT & -1.964857 & 1.055425 & -1.861674 & 0.0630 \\
ROE & 0.013036 & 0.007639 & 1.706541 & 0.0883 \\
FA/TA & -3.204574 & 0.719724 & -4.452505 & 0.0000 \\
\hline \multicolumn{5}{c}{ Effects Specification } \\
\hline Mean dependent var & -0.193186 & S.D. dependent var & 4.126527 \\
S.E. of regression & 4.016116 & Sum squared resid & 13177.55 \\
J-statistic & 19.24496 & Instrument rank & 26 \\
\hline
\end{tabular}

In empirical analysis, we examined the relationship between corporate liquidity and funding sources in energy sector in the Czech Republic. We investigated which variables have an effect on liquidity of companies in energy sector. Table 3 suggests that liquidity of companies was influenced by variables such as equity ratio, share of earnings before interest and taxes to total assets, return on equity and share of fixed assets to total assets in energy sector in the Czech Republic from 20007 to 2015. Some of the independent variables were not statistically significant, thus we are not able to confirm the impact of these variables on liquidity of companies in the Czech Republic. For this fact, Table 3 indicates only statistically significant variables that have impact on liquidity of companies in energy sector in the Czech Republic.

The empirical analysis shows that there is a negative impact of share of earnings before interest and taxes to total assets (EBIT) on liquidity of companies in energy sector. This means that increase of EBIT of unit decreases the corporate liquidity of 1.964857 units. This results confims study of Trippner (2013) who found negative relationship between corporate liquidity and share of earning before interest and taxes to total assets. More profitable companies are the ones that can use their retained earnings in order to finance their investment projects. We can argue that the more liquid the firm is, it is the less leveraged.

The empirical results indicate that there is a negative impact of share of fixed assets to total assets (FAT/TA) on corporate liquidity. The share of fixed assets to total assets increase by one unit decreases the corporate liquidity of 3.204574 units. This result is not confirmed by any of the above study. The resulting relationship can be explained in the following argument. Assets of the company can be divided into fixed assets and current assets. The liquidity of the company consists of current assets. Liquidity growth should be accompanied by an increase in current assets. From this argument it shows that the growth in current assets is accompanied by a decrease in fixed assets. From this fact, can be inferred negative relationship between liquidity of company and fixed assets.

The result aslo suggest that there is positive impact of return on equity (ROE) on corporate liquidity. The results suggest that the increase of return on equity of unit increases the liquidity of companies of 0.013036 units. This result confirm the findings of Trippner (2013) who found positive relationship between corporate liquidity and return on equity (ROE). More profitable companies are the ones that can use their retained earnings in order to finance their investment projects. We can argue that the more liquid the firm is, it is the less leveraged.

The empirical analysis also shows that there is positive impact of equity ratio (ER) on corporate liquidity. This means that increase of equity ratio of unit increases the corporate liquidity of 7.178679 units. This is not consistent with theoretical bases, which expected a negative relationship between equity ratio and liquidity of companies.

Table 4 presents the resulting relationship between liquidity companies (dependent variables) and funding sources (independent variables) using indicator share of capital for consideration to total assets (DE/TA). 
Table 4. Estimation results between liquidity of companies and funding sources in energy sector with share of capital for consideration to total assets (Source: Authors' calculations)

\begin{tabular}{ccccc}
\hline Variable & Coefficient & Std. Error & t-Statistic & Prob. \\
\hline DE/TA & -4.819899 & 0.994174 & -4.848146 & 0.0000 \\
ER & 2.677686 & 0.465101 & 5.757217 & 0.0000 \\
EBIT & -2.131406 & 1.064430 & -2.002392 & 0.0456 \\
ROE & 0.017488 & 0.005675 & 3.081748 & 0.0021 \\
FA/TA & -3.390199 & 0.723392 & 0.0000 \\
\hline \multicolumn{5}{c}{ Cross-section fixed (orthogonal deviations) } \\
\hline Mean dependent var & -0.193186 & S.D. dependent var & 4.126527 \\
S.E. of regression & 4.009640 & Sum squared resid & 13135.08 & 26 \\
J-statistic & 19.24411 & Instrument rank & 268528 & \\
\hline
\end{tabular}

In empirical analysis, we examined the relationship between corporate liquidity and funding sources in energy sector in the Czech Republic. We investigated which variables have an effect on liquidity of companies in energy sector. Table 4 suggests that corporate liquidity was influenced by variables such as equity ratio, share of earnings before interest and taxes to total assets, return on equity and share of fixed assets to total assets, share of capital for consideration to total assets in energy sector in the Czech Republic from 20007 to 2015. Table 4 indicates statistically significant variables that have impact on corporate liquidity in energy sector in the Czech Republic.

The empirical results suggest that there is negative impact of share of capital for consideration to total assets (DE/TA) on liquidity of companies in energy sector. This means that increase of DE/TA of unit decreases the corporate liquidity of 4.819899 units. This is not consistent with theoretical bases, which expected a positive relationship between share of capital for consideration to total assets and liquidity of companies.

The empirical analysis shows that there is negative impact of share of earnings before interest and taxes to total assets (EBIT) on liquidity of companies in energy sector. This means that increase of EBIT of unit decreases the corporate liquidity of 2.131406 units. This results confims study of Trippner (2013) who found negative relationship between corporate liquidity and share of earning before interest and taxes to total assets. More profitable companies are the ones that can use their retained earnings in order to finance their investment projects. We can argue that the more liquid the firm is, it is the less leveraged.

The empirical results indicate that there is negative impact of share of fixed assets to total assets (FAT/TA) on corporate liquidity. The share of fixed assets to total assets increase by one unit decreases the corporate liquidity of 3.390199 units. This result is not confirmed by any of the above study. The resulting relationship can be explained in the following argument. Assets of the company can be divided into fixed assets and current assets. The liquidity of the company consists of current assets. Liquidity growth should be accompanied by an increase in current assets. From this argument it shows that the growth in current assets is accompanied by a decrease in fixed assets. From this fact, can be inferred negative relationship between liquidity of company and fixed assets.

The result aslo suggest that there is positive impact of return on equity (ROE) on corporate liquidity. The results suggest that the increase of return on equity of unit increases the liquidity of companies of 0.017488 units. This result confirm the findings of Trippner (2013) who found positive relationship between corporate liquidity and return on equity (ROE). More profitable companies are the ones that can use their retained earnings in order to finance their investment projects. We can argue that the more liquid the firm is, it is the less leveraged.

The empirical analysis also shows that there is positive impact of equity ratio (ER) on corporate liquidity. This means that increase of equity ratio of unit increases the corporate liquidity of 2.677686 units. This is not consistent with theoretical bases, which expected a negative relationship between equity ratio and liquidity of companies.

All identified resulting relationships correspond with the conclusions of correlation analysis through which we determined what relationship exists between liquidity of companies and independent variables.

\section{Conclusions}

The aim of this paper was to determine the impact of funding sources on liquidity of companies in energy sector in the Czech Republic from 2007 to 2015. With the purpose to fulfill the aim, we examined existence and character of relationship between selected financial factors (debt equity ratio, share of capital for consideration to total assets, return on equity, share of fixed assets to total assets, share of earnings before interest and taxes to total assets, equity ratio) and liquidity of the companies in energy sector in the Czech Republic. 
We estimated the effect of funding sources (debt equity ratio, share of capital for consideration to total assets, return on equity, share of fixed assets to total assets, share of earnings before interest and taxes to total assets, equity ratio) on corporate liquidity in energy sector in the Czech Republic.

All identified resulting relationships correspond with the conclusions of correlation analysis through which we determined what relationship exists between liquidity of companies and independent variables.

We found that corporate liquidity was positively influenced by the equity ratio (ER) and return on equity (ROE) in energy sector in the Czech Republic. This means that with increase in return on equity and equity ratio increases corporate liquidity in energy sector in the Czech Republic.

On the other hand, we found that corporate liquidity was negatively influenced by the share of earnings before interest and taxes to total assets (EBIT), share of fixed assets to total assets (FA/TA) and share of capital for consideration to total assets (DE/TA). It can stated that with decrease in the share of earnings before interest and taxes to total assets, share of fixed assets to total assets and share of capital for consideration to total assets increases liquidity of companies in energy sector in the Czech Republic. We can say that the more liquid the firm is, it is the less leveraged.

\section{References}

Anderson, R. W. 2002. Capital structure, firm liquidity and growth. Working papers-research series. National Bank of Belgium.

De Jong, A.; Kabir, R.; Nguyen, T. T. 2008. Capital structure around the world: the roles of firm and country-specific determinants, Journal of banking and finance 32: 1954-1969. https://doi.org/10.1016/j.jbankfin.2007.12.034

Haas, R.; Lelyveld I. 2010. Internal capital markets and lending by multinational bank subsidiaries, Journal of Financial Intermediation 19: 1-25. https://doi.org/10.1016/j.jfi.2009.02.001

Hansen, L. P. 1982. Large sample properties of generalized method of moments estimators, Econometrica 50(4): 1029-1054. https://doi.org/10.2307/1912775

Lispon, M. L.; Mortal, S. 2009. Liquidity and capital structure, Journal of Financial Markets 12(4): 611-644. https://doi.org/10.1016/j.finmar.2009.04.002

Mehar, A. 2005. Impacts of equity financing on liquidity position of a firm, Applied Financial Economics 15: 425-438. https://doi.org/10.1080/0960310042000314197

Miloş, M. C. 2015. Capital structure determinants. evidence from the Romanian listed companies. Analele Universitatii 'Eftimie Murgu' Resita. Fascicola II. Studii Economice, 129-134.

Myers, S. C. 2001. Capital structure, The Journal of Economic Perspectives 15(2): 81-102. https://doi.org/10.1257/jep.15.2.81

Růčková, P. 2015. Impact of liquidity and profitability on use of debt finance sources of companies in manufacturing industry in V4 countries, Acta Academica Karviniensia 15(3): 69-79.

Saleem, Q.; Rehman, U. R. 2011. Impacts of liquidity ratios on profitability, Interdisciplinary Journal of Research in Business 1(7): 95-98.

Shah, P. 2012. Evaluation of profitability and liquidity relationship through multivariate working capital analysis, A Management Journal 3(2): 177.

Shleifer, A.; Vishny, R. W. 2003. Stock market driven acquisitions, Journal of Financial Economics 70: $295-311$. https://doi.org/10.1016/S0304-405X(03)00211-3

Stulz, R. 1990. Managerial discretion and optimal financing policies, Journal of Financial Economics 26(1): 3-27. https://doi.org/10.1016/0304-405X(90)90011-N

Šarlija, N.; Harc, M. 2012. The impact of liquidity on the capital structure: a case study of Croatian firms, Business Systems Research 3(1): 30-36. https://doi.org/10.2478/v10305-012-0005-1

Trippner, P. 2013. Analysis of financial liquidity management in the enterprise and its impact on the profitability, 494-501.

Williamson, O. E. 1988. Corporate finance and corporate governance, Journal of Finance 43(3): 567-591. https://doi.org/10.1111/j.1540-6261.1988.tb04592.x 